\title{
Effects of methionine source, arginine:lysine ratio and sodium chloride level in the diets of grower broilers reared under high-temperature conditions
}

-Author(s)
R Montanhini Neto $^{1 *}$
ML Ceccantini $^{1}$
JIM Fernandes ${ }^{2}$
1 Adisseo Brasil Nutrição Animal Ltda.
2 Universidade Federal do Paraná, campus
Palotina.

-Mail Adress

*Corresponding author e-mail address

Adisseo Brasil Nutrição Animal Ltda.,

Avenida Maria Coelho Aguiar, n. 215,

CENESP, Bloco $\mathrm{G}, 1^{\circ}$ andar, CEP 05.804-

900, São Paulo, São Paulo, Brasil. Phone:

+554191161820.

E-mail: roberto.neto@adisseo.com

\section{- Keywords}

DL-methionine, methionine hydroxy analog, intestinal morphology, immunity.

\begin{abstract}
The objective of this study was to evaluate the influence of methionine sources (DL-methionine 99\% powder (DLM) or methionine hydroxy analog liquid 88\% (HMTBA)), arginine:lysine (Arg:Lys) ratio and sodium chloride $(\mathrm{NaCl})$ content in the diet of broilers on their performance, carcass yield, serum biochemistry, duodenal mucosal morphology, and immune response. Birds were kept under high temperature conditions during the grower phase and were inoculated or not with an antigen. The use of HMTBA promoted better live performance and carcass yield than the use of DLM. Diets with 1.05 Arg:Lys ratio resulted in better live performance, higher carcass and breast meat yields, longer villi, shallower crypts, and stronger immune response when broilers were challenged than the 1.40 ratio. The dietary supplementation of 6.0 $\mathrm{g} \mathrm{NaCl} / \mathrm{kg}$ promoted better growth performance and carcass weight than $2.0 \mathrm{~g} \mathrm{NaCl} / \mathrm{kg}$. There was no influence of the different methionine sources or $\mathrm{NaCl}$ concentrations on any evaluated intestinal morphology parameter or immune response, nor of any interactions between these sources of variation.
\end{abstract}

\section{INTRODUCTION}

In broiler production, the fast growth rate imposed by genetic selection, as well as environmental and management stressors and immune challenges (vaccination and infection) of commercial production systems increase the requirements for certain nutrients in broiler diets. These nutrients must be supplied to prevent failure of the birds' immune system or to modulate their immune response. Adequate immune response is essential to achieve good performance under practical conditions (Baker, 2009).

The two main effects of hot climates on poultry are reduced feed or nutrient intake and physiological changes in their metabolism (Attia et al., 2006).The exposure of broilers to high environmental temperatures impairs live performance and carcass yield, and affects bird welfare (Brossi et al., 2009). In addition to the lower feed in take, vascular changes may also contribute to lower nutrient supply because the blood flow to the intestine is considerably reduced under these conditions (Hai et al., 2000).

The ideal amino acid profile leading to optimal growth performance is generally defined under well-controlled conditions. However, such a profile may be different when evaluated under challenging conditions, including heat stress exposure. Moreover, this ideal profile should be redefined according to the objective targeted, such as immune system performance, muscle development and/or carcass yield (Pope \& Emmert, 2002). 
According to Kidd et al. (2000), knowledge of the requirements for methionine (Met), lysine (Lys) and threonine (Thr) in broiler diets, which are the first three limiting amino acids, is based on a large volume of scientific information. The identification of the fourth limiting amino acid is important for the development of diet formulation with low crude protein levels. Literature presents several possible candidates for fourth limiting amino acid in practical diets, including isoleucine, valine, tryptophan, and arginine, depending on the ingredients used in feed formulation and on environmental temperature (Kidd \& Hackenhaar, 2005). Arginine (Arg) is considered to be the fourth limiting amino acid when the environmental temperature exceeds the thermal comfort zone of broilers, a common situation in commercial production systems in tropical countries, such as Brazil (Mendes et al., 1997; Viola et al., 2009).

Despite the significant progress made, amino acid requirements and/or ideal amino acid profiles of broilers submitted to high environmental temperatures have not been fully elucidated. Moreover, there is still a lack of consistent data on the immune responses of birds relative to their Met requirements and arginine:lysine (Arg:Lys) ratio under such conditions (Chen et al., 2005; Gonzalez-Esquerra \& Leesson, 2006).

In addition to the important interaction with dietary Arg:Lys ratio, Met source needs to be evaluated because some studies have shown that high temperatures negatively influence the performance of broilers supplemented with DL-methionine (DLM) to a greater extent than those fed with DL-2-hydroxy4-(methylthio)-butanoic acid (DL-HMTBA; Swick \& Pierson, 1988; Swick et al., 1990; Knight et al., 1994; Gonzalez-Esquerra \& Leesson, 2006). In a recent study, Willemsen et al. (2011) concluded that HMTBA supplementation partially prevented the growthdepressing effects of chronic heat exposure compared with DLM supplementation. Those authors suggest that HMTBA is more efficient in alleviating oxidative damage induced by high temperatures because of a more favorable production of glutathione through better trans-sulfuration, as previously demonstrated (Martin-Venegas et al., 2006). Balnave et al. (1999) concluded that the efficiency of Met sources under high temperatures depends on the dietary ratio of Arg to Lys, and observed that the performance of broilers fed with HMTBA was optimized when a high Arg:Lys ratio (1.36) was fed.

Interactions between dietary electrolytes and Arg:Lys ratio have been observed in experiments conducted under situations of high environmental temperature (Brake et al., 1998; Balnave \& Brake, 2001; Chen et al., 2005). In particular, Brake et al. (1998) found that under heat-stress conditions, increasing Arg:Lys ratio improved weight gain when $\mathrm{NaCl}$ content was low (1.2 g/kg of feed), while no improvement was observed with high dietary $\mathrm{NaCl}$ content $(2.4 \mathrm{~g} / \mathrm{kg}$ of feed). Chen et al. (2005) confirmed these results by showing that reductions in Arg and Lys digestibility are dependent on the ratio between these amino acids and dietary $\mathrm{NaCl}$ concentration. Indeed, with high dietary $\mathrm{NaCl}$ contents (from 3 to $6 \mathrm{~g} / \mathrm{kg}$ ), the digestibility of both Arg and Lys decreased. Moreover, these authors demonstrated that both Arg and Lys digestibility were affected when their ratio was 1.05 , but not when it was 1.35 .

According to Ribeiro et al. (2008a), under the heatstress conditions typical of Brazilian summers, higher Na levels $(0.25 \%$ during the starter phase and $0.22 \%$ during the grower phase) improve feed conversion ratio. Those authors found that under the same hot conditions, better feed conversion and weight gain results were achieved when diets were formulated with HMTBA compared with DLM. Motl et al. (2005) reported a significant interaction between Met level, Met source and $\mathrm{Na}$ level in the diet of broilers submitted to high environmental temperatures. A possible explanation may be that the efficiency of DLM absorption is directly associated with $\mathrm{Na}$ levels in the intestinal lumen, whereas HMTBA absorption is less dependent on the level of this electrolyte and partially occurs by passive diffusion (Branchet \& Puigserver, 1989; Dibner et al., 1992; Knight et al., 1994; Maenz \& Engele-Schann, 1996; Martin-Venegas et al. 2008).

The objective of this study was to evaluate the influence of Met source (DL Mor HMTBA), digestible Arg:Lys ratio (1.05 and 1.40), and $\mathrm{NaCl}$ level (2.0 and $6.0 \mathrm{~g} / \mathrm{kg}$ ) in the diet of broilers reared under chronic high environmental temperatures from 21 to 42 days of age and challenged or not with bovine serum albumin (BSA) on their performance, immune response, serum biochemistry, duodenal mucosal morphometrics, and carcass yield.

\section{MATERIAL AND METHODS}

In this study, 960 one-day-old male Cobb 500 broiler chicks were housed according to a completely randomized design in a $2 \times 2 \times 2$ factorial arrangement, consisting of the dietary inclusion of two Met sources (DLM or HMTBA), two Arg:Lys ratios (1.05 or 1.40), 
and two $\mathrm{NaCl}$ levels (2.0 or $6.0 \mathrm{~g} / \mathrm{kg}$ ), making up eight treatments with four replicates each, totaling 32 experimental units (Table 1).

Table 1 - Treatments applied during the grower phase (21 to 42 days).

\begin{tabular}{lccc}
\hline Treatment & $\begin{array}{c}\text { Methionine } \\
\text { source }\end{array}$ & $\begin{array}{c}\text { Arginine: lysine } \\
\text { ratio }\end{array}$ & $\mathrm{NaCl}$ level $(\mathrm{g} / \mathrm{kg})$ \\
\hline 1 & DLM $^{1}$ & 1.05 & 2.0 \\
2 & DLM & 1.05 & 6.0 \\
3 & DLM & 1.40 & 2.0 \\
4 & DLM & 1.40 & 6.0 \\
5 & HMTBA $^{2}$ & 1.05 & 2.0 \\
6 & HMTBA & 1.05 & 6.0 \\
7 & HMTBA & 1.40 & 2.0 \\
8 & HMTBA & 1.40 & 6.0 \\
\hline
\end{tabular}

1 DLM: DL-methionine powder (99\%). ${ }^{2}$ HMTBA: methionine hydroxy analog liquid (88\%).

Water and feed were offered ad libitum according to a feeding program divided into two phases: a starter phase, from 1 to 20 days of age, and a grower phase, from 21 to 42 days of age. During the starter phase, all broilers received the same commercial diet. Two basal diets were formulated for the grower phase (21 to 42 days), containing different Met sources (DLM or HMTBA) and with the inclusion of inert material (clay), which was replaced with L-arginine (treatments with 1.40 Arg:Lys ratio) and $\mathrm{NaCl}$ (treatments with $6.0 \mathrm{~g} /$ kg; Table 2).

Broilerswere housed in an environmentally-controlled house, equipped with exhaustion fans, cooling pads, an electronic panel to control house temperature and humidity, and heating hoods connected to a control board. Broilers were distributed into $3.75-\mathrm{m}^{2}$ pens, with $\pm 10 \mathrm{~cm}$ deep wood-shavings litter. During the starter phase, birds were reared under thermal comfort, according to age ( 1 to 7 days: 28 to $33^{\circ} \mathrm{C}$; 8 to 14 days: 24 to $28^{\circ} \mathrm{C}$; 15 to 21 days: 22 to $25^{\circ} \mathrm{C}$ ). From 21 to 42 days of age, broilers were exposed to cyclic heat stress (30 to $32^{\circ} \mathrm{C}$ for five hours daily).

On day 21, four broilers per replicate were identified using leg bands and were then inoculated with BSA diluted in phosphate buffer solution for subsequent determination of anti-BSA antibodies, as described by Ribeiro et al. (2008b). Other four broilers per replicate, duly identified, were inoculated with phosphate buffer solution, and considered as a negative control group.

Mean body weight and mean feed intake per experimental unit were recorded when broilers were 21 and 42 days of age. In case of death, the body weight of the dead birds was recorded to calculate corrected feed conversion ratio.
Table 2 - Ingredient composition and calculated nutritional values of the experimental diets fed during the grower phase (21 to 42 days).

\begin{tabular}{|c|c|c|}
\hline Ingredients (\%) & $\begin{array}{l}\text { Feeds with DLM } \\
\text { (T1-T4) }\end{array}$ & $\begin{array}{c}\text { Feeds with HMTBA } \\
\text { (T5-T8) }\end{array}$ \\
\hline Corn & 59.500 & 59.600 \\
\hline Soybean meal & 31.900 & 31.900 \\
\hline Limestone & 1.000 & 1.000 \\
\hline Dicalcium phosphate & 1.600 & 1.600 \\
\hline Vegetable oil & 4.150 & 4.110 \\
\hline Inert $^{1}$ & 1.000 & 1.000 \\
\hline $\mathrm{DLM}^{2}$ & 0.264 & - \\
\hline $\mathrm{HMTBA}^{3}$ & - & 0.300 \\
\hline L-lysine $80 \%$ & 0.180 & 0.180 \\
\hline L-threonine 98\% & 0.070 & 0.070 \\
\hline Vitamin and mineral premix & 0.300 & 0.300 \\
\hline \multicolumn{3}{|l|}{ Calculated nutritional values } \\
\hline Protein (g/kg) & 198.0 & 198.0 \\
\hline Metabolizable energy (kcal/kg) & 3151 & 3151 \\
\hline Calcium (g/kg) & 8.30 & 8.30 \\
\hline Available phosphorus (g/kg) & 4.10 & 4.10 \\
\hline Digestible lysine (\%) & 1.12 & 1.12 \\
\hline Digestible methionine (\%) & 0.78 & 0.78 \\
\hline Digestible threonine (\%) & 0.71 & 0.71 \\
\hline Digestible arginine (\%) & 1.18 & 1.18 \\
\hline
\end{tabular}

1 Partially replaced by $0.388 \% \mathrm{~L}-\mathrm{Arg}+0.2 \% \mathrm{NaCl}$ (T3 and T7); partially replaced by $0.388 \% \mathrm{~L}-\mathrm{Arg}+0.6 \% \mathrm{NaCl}$ (T4 and T8); partially replaced by $0.2 \% \mathrm{NaCl}$ (T1 and T5); partially replaced by $0.6 \% \mathrm{NaCl}$ (T2 and T6). ${ }^{2} \mathrm{DLM}$ : DL-methionine powder (99\%). ${ }^{3}$ HMTBA: methionine hydroxy analog liquid (88\%).

Blood samples without anti-clotting agent were collected by jugular or brachial vein puncture from two inoculated and two control birds from each experimental unit at 21, 28, 35 and 42 days. The collected sera were analyzed for antibody levels using an ELISA protocol, with BSA asantigen (Steinitz, 2000).

At 42 days of age, two birds per replicate (eight birds per treatment) were euthanized by neck dislocation in order to collect liver and cloacal bursa esamples, which were stored in buffered formalin (10\%). Livert issue samples were processed and stained with hematoxylin and eosin (HE) for histological analysis, examining the presence of lymphoid clusters and liver tissue morphology. Portions of the liver with lymphoid clusters were quantified throughout the glass slide 
using light microscopy at 10x magnification. The cloacal bursae were paraffin-embedded and taken to a rotary microtome to obtain 5 - $\mu$ m thick cross-sections from the center of the organ, which were subsequently stained with HE. Slides were digitalized according to the following parameters: brightness ranging between 125 and 145\%, 185\% contrast and 800\% scale. Images were saved as jpg files and read in an image analyzer. Cloacal bursae images were read and measured using an image-analysis software (Image-Pro Plus 5.2, Media Cybernetics). Total cross-sectional area of the bursae and lymphoid tissues was measured, and the percentage of lymphoid tissue in relation to total area of the cloacal bursae was calculated.

At 42 days of age, blood samples were collected from four broilers per experimental unit - two challenged and two unchallenged with BSA - to evaluate granulocyte:lymphocyte ratio. Granulocytes (basophils, eosinophils and heterophils), monocytes, and lymphocytes were counted on blood smears according to their different morphology and the ratios among different cell types were calculated (Schmidt et al., 2007).

Antibody levels were analyzed in the sera obtained from two inoculated and two control birds from each experimental unit using an ELISA protocol with bovine serum albumin as antigen. Optical density was read in a spectrophotometer with a $495 \mathrm{~nm}$ filter. Uric acid, urea, and creatinine serum levels were determined using a commercial diagnostic kit (Labtest), and a semi-automatic biochemistry analyzer (Drakae, model Kuicklab).

At 42 days of age, the same broilers that were euthanized by neck dislocation for microscopic evaluation of the liver and cloacal bursae were also used for duodenal mucosa morphometric analysis. Duodenal fragments of approximately five centimeters in length were removed (between the pylorus and the distal portion of the duodenal loop), longitudinally opened on Styrofoam plates and washed with saline solution. Samples were fixed in formaldehyde solution and embedded in paraffin. Each fragment was cut in semi-serial sections (5- $\mu \mathrm{m}$ thick) and stained with HE. For the morphometrical study, images were captured by light microscopy, using a computerized image analysis system (Image-Pro Plus, Version 5.2, Media Cybernetics). The height of twenty villi and the depth of twenty crypts were measured in one section per segment, and their average was calculated (IAC, 1995).

Carcass yield was calculated as hot eviscerated carcass weight (without feet, head, and abdominal fat) relative to live body weight, which was individually measured before slaughter. Prime cuts yield included whole breast yield (with skin and bones) and leg yield (thighs and drumsticks with bones and skin), also calculated relative eviscerated carcass weight. The abdominal fat around the cloaca, cloacal bursa, gizzard, proventriculus and adjacent abdominal muscles was removed and weighed, as described by Smith (1993).

The individual effects and the interactions of the variation sources (dietary Met source, Arg:Lys ratio and $\mathrm{NaCl}$ levels supplied to broilers between 3 to 6 weeks of age) on the studied parameters were evaluated. Data were submitted to analysis of variance, and, when effects were significant, means were compared by the test of Fisher LDS test, using the statistical package Statistica v.8 (Hill \& Lewicki, 2007).

\section{RESULTS AND DISCUSSION}

No interactions among the factors tested were observed $(p>0.05)$. Under the present experimental conditions, a Met source effect was observed on feed conversion ratio, which was significantly $(p<0.05)$ lower in HMTBA-fed birds compared with DLM-fed birds (Table 3). This effect of Met source has been reported by several authors (Swick \& Pierson, 1988; Swick et al., 1990; Knight et al., 1994; Willemsen et al.,

Table 3 - Performance of broilers fed diets formulated using different methionine sources, arginine:lysine ratios and sodium chloride levels from 21 to 42 days of age.

\begin{tabular}{|c|c|c|c|}
\hline & Weight gain (g) & Feed intake(g) & Feed conversion ratio \\
\hline \multicolumn{4}{|c|}{ Methionine source } \\
\hline DLM & $1878.71 \pm 26.64$ & $3804.18 \pm 26.47$ & $2.03^{\mathrm{a}} \pm 0.02$ \\
\hline HMTBA & $1915.68 \pm 32.56$ & $3758.74 \pm 56.67$ & $1.97^{b} \pm 0.03$ \\
\hline \multicolumn{4}{|c|}{ Arginine:lysine ratio } \\
\hline 1.05 & $1938.78^{a} \pm 21.79$ & $3805.45 \pm 42.68$ & $1.96^{\mathrm{b}} \pm 0.02$ \\
\hline 1.40 & $1855.61^{b} \pm 33.31$ & $3757.47 \pm 45.64$ & $2.03^{\mathrm{a}} \pm 0.03$ \\
\hline \multicolumn{4}{|c|}{$\mathrm{NaCl}$ level (g/kg) } \\
\hline 2.0 & $1844.48^{\mathrm{b}} \pm 26.09$ & $3793.40 \pm 25.60$ & $2.06^{a} \pm 0.02$ \\
\hline 6.0 & $1949.91^{a} \pm 27.64$ & $3769.53 \pm 57.50$ & $1.93^{b} \pm 0.02$ \\
\hline
\end{tabular}

Means followed by different letters indicate significant difference $(p<0.05)$ between treatments within a same factor by the Fisher LSD test. No interactions between the tested factors were observed $(p>0.05)$. 
2011). According to Willemsen et al. (2011), the effect of HMTBA may be attributed to a better redox status, which, in turn, is linked to a higher reduced glutathione/ total glutathione ratio in HMTBA-fed birds. This effect of HMTBA on glutathione status may be linked to the better trans-sulfuration ability of HMTBA compared to DLM, as reported by Martin-Venegas et al. (2006). Recent studies reported that HMTBA is able to better maintain the redox status under different conditions compared with DLM, both in broilers (Swennen et al., 2011) and mice (Tang et al., 2011).

There was a significant effect $(p<0.05)$ of $\mathrm{NaCl}$ level on the live performance. The level of $6.0 \mathrm{~g} /$ $\mathrm{kg}$ promoted higher weight gain and better feed conversion than $2.0 \mathrm{~g} / \mathrm{kg}$. Similarly, the Arg:Lys ratio of 1.05 improved $(p<0.05)$ broiler weight gain and feed conversion. Consistent results were reported in other studies, where an increase in Arg:Lys ratio improved the performance of broilers reared under high environmental temperatures (Brake et al., 1998; Balnave \& Brake, 2001; Costa et al., 2001; Chen et al., 2003; Chen et al., 2005). No interaction was detected between tested factors ( $p>0.05$ ) for live performance parameters.

Balnave et al. (1999) observed a progressive decline in weight gain when broilers received DLM in their diet and when the Arg:Lys ratio increased from 1.03 to 1.34. Chen et al. (2003) also evaluated the interaction between Met sources and Arg:Lys ratios in diets with DLM and HMTBA and observed an increase in weight gain when broilers were kept under of heat stress conditions with increasing Arg:Lys ratios (1.04-1.19 to 1.35), in the presence of HMTBA, but not of DLM.
Balnave \& Brake (2004), in a review on the effects of environmental temperature and dietary composition on the effectiveness of DLM and HMTBA, concluded that, in diets with low Arg:Lys ratio (1.05) and high $\mathrm{NaCl}$ levels, supplementation with DLM was more effective, while in diets with high Arg:Lys ratio (1.35) and low $\mathrm{NaCl}$ levels, performance was better when the diet was supplemented with HMTBA.

The use of HMTBA promoted better results ( $p>0.05)$ in carcass yield and leg weights, but no difference ( $p>0.05)$ was observed in breast meat weight between the tested Met sources (Table 4). The present results indicate that HMTBA can provide higher net quantities of Met to the body. Methionine is considered an essential amino acid for meat production and development (Liu et al., 2010). Consistent results were reported by other authors (Esteve-Garcia \& Liaurado, 1997; Ribeiro et al., 2005; Bunchasak et al., 2006).

A significant effect of $\mathrm{NaCl}$ level $(p<0.05)$ was observed, with the level of $6.0 \mathrm{~g} / \mathrm{kg}$ promoting higher carcass, leg, and breast weights (Table 4). Diets with the low Arg:Lys ratio (1.05) resulted in significant $(p<0.05)$ increase in carcass and breast meat weights. Mahmoud \& Teeter (1996) supplied broilers kept under high temperature conditions with diets with Arg:Lys ratios of 1.10 and 1.40, and obtained better breast meat yield as Arg:Lys ratio increased. Costa et al. (2001) showed that increasing Arg:Lys ratio linearly improved leg yield and reduced abdominal fat deposition. No interaction among the tested factors ( $p>0.05$ ) was found in the present experiment for carcass and parts yields.

Regarding duodenal mucosa morphometrics of immune-unchallenged broilers, there was a significant

Table 4 - Carcass yield of broilers fed diets formulated using different methionine sources, arginine:lysine ratios and sodium chloride levels from 21 to 42 days of age.

\begin{tabular}{|c|c|c|c|c|}
\hline & Carcass weight (g) & Breast meat (g) & Legs $(g)$ & Abdominal fat (g) \\
\hline \multicolumn{5}{|c|}{ Methionine source } \\
\hline DLM & $2171.71^{\mathrm{b}} \pm 41.81$ & $785.61 \pm 18.03$ & $600.31^{b} \pm 10.72$ & $38.56 \pm 2.11$ \\
\hline HMTBA & $2262.20^{a} \pm 43.66$ & $806.94 \pm 19.41$ & $625.47^{a} \pm 12.82$ & $42.62 \pm 2.03$ \\
\hline \multicolumn{5}{|c|}{ Arginine:lysine ratio } \\
\hline 1.05 & $2268.37^{a} \pm 39.58$ & $821.50^{\mathrm{a}} \pm 16.40$ & $619.87 \pm 10.48$ & $40.94 \pm 1.81$ \\
\hline 1.40 & $2159.10^{\mathrm{b}} \pm 45.23$ & $770.58^{b} \pm 20.09$ & $604.60 \pm 13.32$ & $40.25 \pm 2.36$ \\
\hline \multicolumn{5}{|c|}{$\mathrm{NaCl}$ level (g/kg) } \\
\hline 2.0 & $2140.97^{b} \pm 42.37$ & $764.12^{b} \pm 18.11$ & $598.13^{b} \pm 12.65$ & $38.92 \pm 2.23$ \\
\hline 6.0 & $2290.03^{a} \pm 40.23$ & $829.81^{a} \pm 17.66$ & $626.84^{a} \pm 10.64$ & $42.26 \pm 1.91$ \\
\hline
\end{tabular}

Means followed by different letters indicate significant difference $(p<0.05)$ between treatments within a same factor by the Fisher LSD test. No interactions between the tested factors were observed $(p>0.05)$. 
Table 5 - Duodenal mucosal morphometrics of broilers fed diets formulated with different methionine sources, arginine:lysine ratios and sodium chloride levels from 21 to 42 days of age.

\begin{tabular}{lccc}
\hline & Villus height $(\mu \mathrm{m})$ & Crypt depth $(\mu \mathrm{m})$ & Villus:Crypt ratio \\
\hline Methionine source & & & \\
\hline DLM & $490.26 \pm 18.96$ & $60.73 \pm 1.70$ & $8.07 \pm 0.36$ \\
HMTBA & $492.48 \pm 17.21$ & $63.82 \pm 2.06$ & $7.78 \pm 0.44$ \\
\hline Arginine:lysine ratio & & & \\
\hline 105 & $517.14^{\mathrm{a}} \pm 16.73$ & $65.50 \pm 2.19$ & $7.90 \pm 0.44$ \\
140 & $469.60^{b} \pm 17.50$ & $59.05 \pm 1.62$ & $7.95 \pm 0.38$ \\
\hline NaCl level $(\mathrm{g} / \mathrm{kg})$ & & & \\
\hline 2,0 & $512.41 \pm 17.57$ & $64.41 \pm 2.21$ & $7.96 \pm 0.41$ \\
6,0 & $474.33 \pm 17.36$ & $60.14 \pm 1.44$ & $7.89 \pm 0.41$ \\
\hline
\end{tabular}

Means followed by different letters indicate significant difference $(p<0.05)$ between treatments within a same factor by the Fisher LSD test. There was only one interaction between methionine source and arginine:lysine ratio ( $p>0.05)$.

effect $(p<0.05)$ of Arg:Lys ratio on villus height (Table 5). Diets with Arg:Lys ratios of 1.05 resulted in longer villi. In addition, there was a significant interaction $(p<0.05)$ between Met sources and Arg:Lys ratios for crypt depth: broilers fed diets with 1.05 Arg:Lys ratio and supplemented with HMTBA had deeper crypts compared with those supplemented with DLM (Table 6). Villus height and crypt depth indicate the quality of intestinal morphology (Sukhotnik et al., 2005). Several studies reported that HMTBA has a significant antibacterial effect on the intestines of monogastric animals (Dibner \& Buttin, 2002). It has been shown that the acid properties of HMTBA may inhibit the growth of enteric pathogens (Wang et al., 2006).

Table 6 - Breakdown of the interaction between methionine source and arginine:lysine ratio for depth of the crypts of immune-unchallenged broilers from 21 to 42 days of age.

\begin{tabular}{lll}
\hline Arginine:lysine ratio & DL-methionine & $\begin{array}{l}\text { Methionine hydroxy } \\
\text { analog }\end{array}$ \\
\hline 105 & $62.96^{\mathrm{B}}$ & $68.05^{\mathrm{aA}}$ \\
140 & 58.50 & $59.59^{\mathrm{b}}$ \\
\hline
\end{tabular}

Means followed by different lower-case letters indicate significant difference $(p<0.05)$ between Arg: Lys ratios, and means followed by different capital letters indicate signifi can't difference $(p<0.05)$ between Met sources by the Fisher LSD test.

The evaluated parameters of broilers challenged with BSA were significantly different $(p<0.05)$ only when Arg:Lys ratio was changed. The highest Arg:Lys ratio increased crypt depth. In a study with piglets, Liu et al. (2008) found that Arg supplementation increased protein production by the mucosa due to higher DNA expression. Those authors observed increased villus height and reduced crypt depth with the addition of Arg, indicating that supplementation with this amino acid is able to help protecting the intestinal mucosa from damage caused by bacterial challenges. No significant differences ( $p>0.05)$ were observed for any morphometric measurements of the duodenal mucosa when broilers challenged or not with BSA were compared.

Moreover, no interaction was detected among the tested factors ( $p>0.05$ ) for serum biochemical parameters. Urea and uric acid serum levels were not influenced by the evaluated factors, with the exception of creatinine levels, which were significantly higher $(p<0.05)$ in broilers supplemented with the lowest $\mathrm{NaCl}$ level and unchallenged. Serum biochemical parameters were not influenced $(p>0.05)$ by BSA challenge.

The near absence of differences between treatments with and with no BSA inoculation may be related to the immune status of the birds kept under heat stress, which could have prevented any enhancement of the birds' immune response. Several trials were performed using BSA to stimulate the immune system of poultry (Kikusato et al., 2010; Soleimani et al., 2011; Al-Khalifa et al., 2012), but some authors reported that, under stressful conditions, e.g., extreme heat or health challenges, animals are unable to elicit a relevant immune response against external antigens (Cheville, 1979; Siegel, 1987; Rivas \& Fabricant, 1988; El-Lethey et al., 2003). In addition, the variation observed in immune parameters was often very wide, not allowing the detection of any statistical differences among treatments (Liu et al., 2002; Mashaly et al. 2004). Therefore, in the present study, the results clearly evidence that the birds were indeed reared under heat stress.

Under neutral temperature conditions, Arg interacts with Met in the biosynthesis of creatinine (Chamruspollert et al., 2002). Arg transfers one guanidine group to glycine by the action of amidinotransferase, forming ornithine and guanidinoacetate. In a second reaction, catalyzed by guanidinoacetate $\mathrm{N}$-methyltransferase, guanidinoacetate is methylated by S-adenosylmethionine to produce creatinine (Gonzalez-Esquerra \& Lesson, 2006). Creatinine is then released by the liver and mainly captured by the muscle tissue, where it is stored as phosphocreatine or converted into creatinine; both of these molecules can be excreted by the kidneys ( $\mathrm{Wu}$ \& Morris, 1998).

No interactions were observed ( $p>0.05)$ between morphometrics of the cloacal bursae, granulocyte: 
lymphocyte ratio, or lymphoid clusters in liver tissue and broiler experimental inoculation status (Table 7). The lymphoid tissue area of the cloacal bursae of birds inoculated with BSA and supplemented with the lowest Arg:Lys ratio was smaller than that of birds supplemented with the highest Arg:Lys ratio. BSA inoculation negatively affected lymphoid tissue areas of the cloacal bursae, independently of treatment, whereas control broilers experienced no such effect. Inoculation with BSA reduced lymphoid tissue area of the cloacal bursae in immune-challenged birds compared with the controls. In addition, in inoculated birds, those fed the lowest Arg:Lys ratio presented smaller area $(p<0.05)$ than broilers fed the Arg:Lys ratio, suggesting stronger immune response to the antigen.

Arg is also known to influence immunity and disease resistance. According to Le Floc'h et al. (2004), two metabolic pathways have direct immune modulatory effects: the first refers to the conversion of Arg into ornithine and the generation of polyamines, and the second corresponds to the synthesis of nitrous oxide, which, in addition of being a strong vasodilator, is the main cytotoxic mediator of immune-activated cells and the most important regulatory molecule of the immune system (Dusse et al., 2003). It was reported that Arg can also act as a metabolic regulator, stimulating protein synthesis and reducing protein catabolism under conditions of infection and stress, by stimulating the secretion of insulin, growth hormone and glucagon (Wu et al., 2000; Frank et al., 2007).

In conclusion, when broilers were reared under hightemperature conditions, the use of diets containing HMTBA, 1.05 Arg:Lys ratio and $6.0 \mathrm{~g} \mathrm{NaCl} / \mathrm{kg}$ of feed promoted better performance and carcass yield. Different Met sources and different $\mathrm{NaCl}$ levels has no effect on intestinal morphology, serum biochemistry or immune response; however, increasing Arg:Lys ratio in the diet positively influences these parameters when broilers are reared under high environmental temperature conditions and are immune challenged.

\section{ACKNOWLEDGMENTS}

The authors would like to thank Adisseo Brazil Animal Nutrition Ltda. for funding the present research study and the PENA study group of the Federal University of Paraná, Palotina campus, for conducting and analyzing of this experiment.

\section{REFERENCES}

Al-Khalifa H, Givens DI, Rymer C, Yaqoob P. Effect of n-3 fatty acids on immune function in broiler chickens. Poultry Science 2012;91(1):74-88.

Attia YA, Böhmer BM, Roth-Maier DA. Responses of broiler chicks raised under constant relatively high ambient temperature to enzymes, amino acid supplementations, or a high-nutrient diet. Archiv fur Geflugelkunde 2006;70(2):80-91

Baker DH. Advances in protein-amino acid nutrition of poultry. Amino Acids 2009;37(1):29-41

Balnave D, Brake J. Different responses of broilers at low, high or cyclic moderate-high temperatures to dietary sodium bicarbonate supplementation due to differences in dietary formulation. Australian Journal of Agricultural Research 2001;52(6):609-613

Balnave D, Brake J. Evidence supporting the hypothesis that ambient temperature and dietary composition influence the relative efficacy of methionine and its hydroxy analogues for broilers: A Review. The Journal of Applied Poultry Research 2004;13(4):693-700.

Balnave D, Hayat J, Brake J. Dietary arginine:lysine ratio and methionine activity at elevated environmental temperatures. The Journal of Applied Poultry Research 1999;8(1):1-9.

Brake J, Balnave D, Dibner JJ. Optimum dietary arginine: lysine ratio for broiler chickens is altered during heat stress in association with changes in intestinal uptake and dietary sodium chloride. British Poultry Science 1998;39(5):639-647.

Table 7 - Immuneparameters of broilers fed diets formulated using different methionine sources, arginine:lysine ratios and sodium chloride levels from 21 to 42 days of age.

\begin{tabular}{|c|c|c|c|c|}
\hline & Cloacal bursae $\left(\mathrm{mm}^{2}\right)$ & Lymphoid tissue $\left(\mathrm{mm}^{2}\right)$ & Lymphoid clusters & Optical density (ELISA) \\
\hline \multicolumn{5}{|c|}{ Methionine source } \\
\hline DLM & $113.00 \pm 7.09$ & $22.14 \pm 2.04$ & $4.72 \pm 0.94$ & $0.353 \pm 0.01$ \\
\hline HMTBA & $113.39 \pm 8.46$ & $24.40 \pm 2.42$ & $3.97 \pm 0.40$ & $0.332 \pm 0.01$ \\
\hline \multicolumn{5}{|c|}{ Arg:Lys ratio } \\
\hline 105 & $110.49 \pm 8.96$ & $23.52^{b} \pm 2.47$ & $4.53 \pm 0.85$ & $0.335 \pm 0.01$ \\
\hline 140 & $115.67 \pm 6.48$ & $26.90^{\mathrm{a}} \pm 2.04$ & $4.15 \pm 0.57$ & $0.350 \pm 0.01$ \\
\hline \multicolumn{5}{|c|}{$\mathrm{NaCl}$ level $(\mathrm{g} / \mathrm{kg})$} \\
\hline 2.0 & $112.66 \pm 8.87$ & $23.73 \pm 2.23$ & $4.53 \pm 0.74$ & $0.353 \pm 0.01$ \\
\hline 6.0 & $113.44 \pm 6.90$ & $22.88 \pm 2.26$ & $4.16 \pm 0.70$ & $0.330 \pm 0.01$ \\
\hline
\end{tabular}

Means followed by different letters indicate significant difference $(p<0.05)$ between treatments within a same factor by the Fisher LSD test. No interactions between the tested factors were observed ( $p>0.05)$. 
Branchet P, Puigserver A. Na-independent and non-steriospecific transport of 2-hydroxy 4-methylthiobutanoic acid by brush border membrane vesicles from chick small intestine. Comparative Biochemistry and Physiology 1989;94(1):157-163.

Brossi C, Contreras-Castillo CJ, Amazonas EA, Menten JFM. Estresse térmico durante o pré-abate em frangos de corte. Ciência Rural 2009:39(4):1284-1293.

Bunchasak C, Sooksridang T, Chaiyapit R. Effect of adding methionine hydroxy analogue as methionine source at the commercial requirement recommendation on production performance and evidence of ascites syndrome of male broiler chicks fed corn-soybean based. International Journal of Poultry Science 2006;5(8):744-752

Chamruspollert M, Pesti GM, Bakalli RI. Dietary interrelationships among arginine, methionine and lysine in young broiler chicks. British Journal of Nutrition 2002;88(6):655-660.

Chen J, Hayat J, Huang B. Responses of broilers at moderate or high temperatures to dietary arginine:lysine ratio and source of supplemental methionine activity. Australian Journal of Agricultural Research 2003;54(2):177-181.

Chen J, Li X, Balnave D, Brake J. The influence of dietary sodium chloride, arginine:lysine ratio, and methionine source on apparent ileal digestibility of arginine and lysine in acutely heat-stressed broilers. Poultry Science 2005;84(2):294-297.

Cheville NF. Environmental factors affecting the immune response of birds: a review. Avian Diseases 1979;23(2):308-314

Costa FGP, Rostagno HS, Toledo RS, Albino LTF. Efeito da relação arginina:lisina sobre o desempenho e qualidade de carcaça de frangos de corte de 3 a 6 semanas de idade, em condições de alta temperatura. Revista Brasileira de Zootecnia 2001;30(6):2021-2025

Dibner JJ, Atwell CA, Ivey FJ. Effect of heat stress on 2-hydroxy-4methylthio-butanoic acid and DL-methionine absorption measured in vitro. Poultry Science 1992;71(11):1900-1910

Dibner JJ, Buttin P. Use of organic acids as a model to study the impact of gut microflora on nutrition and metabolism. The Journal of Applied Poultry Research 2002; 11(4):453-463.

Dusse LMS, Vieira LM, Carvalho MG. Nitric oxide revision. Jornal Brasileiro de Patologia e Medicina Laboratorial 2003;39(4):343-50.

El-Lethey $H$, Huber-Eicher B, Jungi TW. Exploration of stress-induced immunosuppression in chickens reveals both stress-resistant and stress-susceptible antigen responses. Veterinary Immunology and Immunopathology 2003;95 (3):91-101.

Esteve-Garcia E, Liaurado LL. Performance, breast meat yield and abdominal fat deposition of male broiler chickens fed diets supplemented with DL-methionine or DL-methionine hydroxy analogue free acid. British Poultry Science 1997;38(4):397-404

Frank JW, Escobar J, Nguyen HV, Jobgen SC, Jobgen WS, Davis TA, Wu G. Oral N-carbamylglutamate supplementation increases protein synthesis in skeletal muscle of piglets. The Journal of Nutrition 2007;137(2):315319.

Gonzalez-Esquerra R, Lesson S. Concentrations of putrescine, spermidine, and spermine in duodenum and pancreas as affected by the ratio of arginine to lysine and source of methionine in broilers under heat stress. Poultry Science 2006:85(8):1398-1408.

Hai L, Rong D, Zhang ZY. The effect thermal environment on of digestion of broilers. Journal of Animal Physiology and Animal Nutrition 2000;83(2):57-64.

Hill T, Lewicki P. Statistics: methods and applications. Tulsa: StatSoft; 2007.
IAC. Analytical and quantitative cytology and histology. Northwestern: International Academy of Cytology, Ed. Science Printers and Publishers; 1995.

Kidd MT, Hackenhaar L. Dietary threonine for broilers: dietary interactions and feed additive supplement use. CAB Reviews 2006;1(5):6-12.

Kidd MT, Kerr BJ, Pallard JP, Rao SK, Halley JT. Limiting amino acids responses in commercial broilers. The Journal of Applied Poultry Research 2000;9(2):223-233.

Kikusato M, Ramsey JJ, Amo T, Toyomizu M. Application of modular kinetic analysis to mitochondrial oxidative phosphorylation in skeletal muscle of birds exposed to acute heat stress. FEBS Letters 2010; 584(14):31433148

Knight CD, Wuelling CW, Atwell CA, Dibner JJ. Effect of intermittent periods of high environmental temperature on broiler performance response to sources of methionine activity. Poultry Science 1994;73(5):627-639.

Le Floc'h N, Melchior D, Obled C. Modification of protein and amino acid metabolism during inflammation and immune system activation. Livestock Production Science 2004; 87(1):37-45.

Liu FH, Juan W, Ele Z, Lin L. Effect on chicken serum biochemical and immune parameters in acute heat-stress. Journal of Beijing Agricultural College 2002;4(1):324-335

Liu GQ, Zong K, Zhang LL, Cao SQ. Dietary methionine affects meat quality and myostatin gene exon 1 region methylation in skeletal muscle tissues of broilers. Agricultural Sciences in China 2010;9(9):1338-1346.

Liu Y, Huang J, Hou Y, Zhu H, Zhao S, Ding B, Yin Y, Yi G, Shi J, Fan W. Dietary arginine supplementation alleviates intestinal mucosal disruption induced by Escherichia coli lipopolysaccharide in weaned pigs. British Journal of Nutrition 2008;100(3):552-560

Maenz DD, Engele-Schann CM. Methionine and 2-hydroxy-4methylthiobutanoic acid are transported by distinct $\mathrm{Na}^{+}$-dependent and $\mathrm{H}^{+}$-dependent systems in the brush border membrane of the chick intestinal epithelium. The Journal of Nutrition 1996:126(2):529-536.

Mahmoud HA, Teeter RC. Arginine:lysine ratio effects on performance and carcass variables of broilers reared in thermoneutral and heat stress environments. Poultry Science 1996; 75(S1):88

Martin-Venegas R, Geraert PA, Ferrer R. Conversion of the methionine hydroxy analogue DL-2-hydroxy-(4-methylthio) butanoic acid to sulfurcontaining amino acids in the chicken small intestine. Poultry Science 2006;85(11):1932-1938

Martin-Venegas R, Geraert PA, Ferrer R. Partial $\mathrm{Na}^{+}$dependence of DL2-hydroxy-4-(methylthio) butanoic acid uptake in the chicken small intestine. Poultry Science 2008; 87(7):1392-1394.

Mashaly MM, Hendrcks GL, Kalama MA, Gehad AE, Abbas AO, Patterson $\mathrm{PH}$. Effect of heat stress on production parameters and immune response of commercial laying hens. Poultry Science 2004;83(6):889894

Mendes AA, Watkins SE, England JA, Saleh EA, Waldroup AL, Waldroup PW. Influence of dietary lysine levels and arginine:lysine ratios on performance of broilers exposed to heat or cold stress during the period of three to six weeks of age. Poultry Science 1997;76(3):472-481.

Motl MA, Fritts CA, Waldroup PW. Influence of dietary sodium level on utilization of methionine from DL-methionine and liquid methioninehydroxy analogue. The Journal of Applied Poultry Research 2005;14(14):147-155

Pope T, Emmert JL. Impact of phase-feeding on the growth performance of broilers subjected to high environmental temperatures. Poultry Science 2002;81(4):504-511. 
Ribeiro AML, Dahlke F, Kessler AK. Methionine sources do not affect performance and carcass yield of broilers fed vegetable diets and submitted to cyclic heat stress. Revista Brasileira de Ciência Avícola 2005;7(3):159-164

Ribeiro AML, Kessler AM, Viola TH, Silva ICM, Rubin L, Raber M, Pinheiro C, Lecznieski LF. Nutritional interaction of methionine sources and sodium and potassium levels on broiler performance under Brazilian summer conditions. The Journal of Applied Poultry Research 2008a;17(1):69-78.

Ribeiro AML, Vogt LK, Canal CW, Laganá C, Streck AF. Suplementação de vitaminas e minerais orgânicos e sua ação sobre a imunocompetência de frangos de corte submetidos a estresse por calor. Revista Brasileira de Zootecnia 2008b;37(4):636-644

Rivas $\mathrm{AL}$, Fabricant J. Indications of immunodepression in chicken infected with various strains of Marek's disease virus. Avian Diseases $1988 ; 32(1): 1-8$

Schmidt EMS, Locatelli-Dittrich R, Santin E, Paulillo AC. Patologia clínica em aves de produção - uma ferramenta para monitorar a sanidade avícola - revisão. Archives of Veterinary Sciences 2007;12(3):9-20.

Siegel HS.Effect of behavioral and physical stressors on immune responses. In: Wiepkema PR, editor. Biology of stress in farm animals: an integrate approach. Dordrecht: Martinus Nijhoff Publishers; 1987. p. 39-52.

Smith MO. Nutrient content of carcass parts from broilers reared under cycling high temperatures. Poultry Science 1993;72(11):2166-2171.

Soleimani AF, Zulkifli I, Omar AR, Raha AR. Physiological responses of 3 chicken breeds to acute heat stress. Poultry Science 2011;90(7):14351440

Steinitz M. Quantitation of the blocking effect of tween 20 and bovine serum albumin in elisamicrowells. Analytical Biochemistry 2000;282(2):232238.

Sukhotnik I, Helou H, Mogilner J, Lurie M, Bernsteyn A, Coran AG, Shiloni E. Oral arginine improves intestinal recovery following ischemia-reperfusion injury in rat. Pediatric Surgery International 2005;21(3):191-196.
Swennen Q, Geraert PA, Mercier Y, Everaert N, Stinckens A, Willemsen H, Li $Y$, Decuypere E, Buyse J. Effects of dietary protein content and 2-hydroxy4-methylthiobutanoic acid or dl-methionine supplementation on performance and oxidative status of broiler chickens. British Journal of Nutrition 2011:106(12):1845-1854.

Swick RA, Creswell DC, Dibner JJ, Ivey FJ. Impact of methionine sources on performance of broilers growing under warm and humid conditions. Poultry Science 1990;69(S1):194.

Swick RA, EEM Pierson. Effect of methionine sources and dietary acidulates on broilers during heat stress. Poultry Science 1988;68(S1):208.

Tang $X$, Yang $Y$, Shi $Y$, Le $G$. Comparative in vivo antioxidant capacity of DL-2-hydroxy-4-methylthiobutanoic acid (HMTBA) and DL-methionine in male mice fed a high-fat diet. Journal of the Science of Food and Agriculture 2011;91(12):2166-2172.

Viola TH, Kessler AM, Ribeiro AML, Silva ICM, Krás R.The influence of crude protein level in the basal diet on the determination of lysine requirements for broiler performance and part yields. Revista Brasileira de Ciência Avícola 2009;11(3):155-160

Wang ZS, Cui Q, Liu YG. Effects of 2-hydroxy-4-(methylthio) butanoic acid on inhibiting pathogenic microbes and acidifier in diet of piglet. Chinese Journal of Animal Science 2006;13(1):1123-1134.

Willemsen H, Swennen Q, Everaert N, Geraert PA, Mercier Y, Stinckens A Decuypere $E$, Buyse J. Effects of dietary supplementation of methionine and its hydroxy analog DL-2-hydroxy-4-methylthiobutanoic acid on growth performance, plasma hormone levels, and the redox status of broiler chickens exposed to high temperatures. Poultry Science 2011;90(10):2311-2320.

Wu G, Meininger CJ, Knabe DA, Bazer FW, Rhoads JM. Arginine nutrition in development, health and disease. Current Opinion in Clinical Nutrition \& Metabolic Care 2000;3(1):59-66

Wu G, Morris SM. Arginine metabolism: nitric oxide and beyond. Biochemical Journal 1998; 336(1):1-17. 